\title{
Case report: West-Nile virus infection in two Dutch travellers returning from Israel
}

N Aboutaleb ${ }^{1}$, M FC Beersma², H F Wunderink³, A CTM Vossen³, L G Visser (L.G.Visser@lumc.nl)1

1. Department of Infectious Diseases, Leiden University Medical Centre, Leiden, Netherlands

2. Department of Virology, Erasmus University Medical Centre, Rotterdam, Netherlands

3. Department of Virology, Leiden University Medical Centre, Leiden, Netherlands

Citation style for this article:

Aboutaleb N, Beersma MF, Wunderink HF, Vossen AC, Visser LG. Case report: West-Nile virus infection in two Dutch travellers returning from Israel. Euro Surveill. 2010;15(34): pii=19649. Available online: http://www.eurosurveillance.org/ViewArticle. aspx?Articleld=19649

Article published on 26 August 2010

We report about West Nile virus (WNV) infections in a symptomatic traveller returning from Israel and in her asymptomatic travel companion. Knowledge of the current epidemiological situation in Israel from where WNV cases were reported recently enabled a rapid diagnosis. The described cases serve as a reminder for physicians to consider WNV in the diagnosis of patients returning from areas with potential circulation of the virus.

At the end of July 2010, a Dutch woman in her early thirties presented to our first aid department with fever, retro-orbital headache and a macular rash. The day before she had returned from a 10-day holiday to Israel where she noticed several mosquito bites during a camping trip at the Sea of Galilee. There was no history of tick bites. Five days before presentation, she had suddenly fallen ill with extreme fatigue, myalgia, fever and an increasingly severe headache. Movement of the eyes had been painful. The next day she had developed a burning sensation of the skin that was followed by a skin eruption. The rash started on the trunk and spread to arms and legs.

Upon presentation in the first aid department she did not appear ill. Body temperature was $36.4^{\circ} \mathrm{C}$. There was a generalised macular rash, sparing hands and feet, and no petechiae or eschars were present. Neurological examination revealed no abnormalities. Potential infection with West-Nile virus was suspected because of the clinical picture and recent reports of West Nile virus cases in Israel [1].

Laboratory examination showed a leukopenia of $1.8 \times 10^{9} / \mathrm{L}$ with a predominance of large granular lymphocytes; thrombocyte count was $92 \times 10^{9} / \mathrm{L}$. Infection with Epstein Barr virus, cytomegalovirus, dengue virus, enterovirus and parechovirus was excluded by serology and antigen test or PCR. A lumbar punction was not performed due to missing neurological symptoms. West Nile virus RNA could not be detected in the EDTA plasma sample taken on day five after onset of disease by a TaqMan reverse transcriptase-PCR assay, using a probe for the WN3'NC [2]. However, in a second blood sample obtained fifteen days later, seroconversion for both serum IgG and IgM antibodies against
West Nile virus was detected with an indirect qualitative enzyme-linked immunosorbent assay (ELISA) (Focus Diagnostics, Cypress, California). This assay uses antibody capture technique for the detection of IgM antibodies.

Once the diagnosis was confirmed, serology was performed in the patient's travel companion who reported having had similar complaints, but who had already recovered by the time he returned to the Netherlands. The laboratory results showed that he was seropositive for WNV IgG and IgM. Recovery was uneventful in both patients.

West-Nile virus is endemic in Israel. The largest recent outbreak in humans in Israel occurred in the year 2000 with more than 400 reported cases [3]. Recently, 12 cases of West Nile fever have been reported, centered around the Tel Aviv area [1]. Culex perexiguus, Cx. pipiens, and Aedes caspius are the vectors of West Nile virus in Israel where most cases of West Nile fever occur between August and October. The seasonal occurrence of human cases reaches a peak one month after the mosquito peak [4].

Measures to avoid mosquito bites such as wearing protective clothes and using repellents are recommended during the whole transmission season and this case report serves as a reminder to physicians to consider West Nile fever in patients with fever returning from Israel.

References

1. West Nile fever hits 12 people in Israel, leaving one dead. Haaretz.com [online]. 2 August 2010. Available from: http:// www.haaretz.com/print-edition/news/west-nile-fever-hits-12people-in-israel-leaving-one-dead-1.305379

2. Lanciotti RS, Kerst AJ, Nasci RS, Godsey MS, Mitchell CJ, Savage HM, et al. Rapid detection of West Nile virus from human clinical specimens, Field-collected mosquitoes, and avian samples by a TaqMan reverse transcriptase-PCR assay J Clin Microbiol. 2000 Nov;38(11):4066-71.

3. Chowers MY, Lang R, Nassar F, Ben-David D, Giladi M, Rubinshtein E et al. Clinical characteristics of the West Nile fever outbreak, Israel, 2000. Emerg Infect Dis. 2001;7(4):675-8.

4. Orshan L, Bin H, Schnur H, Kaufman A, Valinsky A, Shulman L, Mosquito vectors of West Nile fever in Israel. J Med Entomol. 2008;45:939-47. 